This item was submitted to Loughborough's Research Repository by the author.

Items in Figshare are protected by copyright, with all rights reserved, unless otherwise indicated.

\title{
Modernism's legacy: dialogue, objectivity, and justice in Mark Bevir's Democratic Governance
}

PLEASE CITE THE PUBLISHED VERSION

http://dx.doi.org/10.1080/03003930.2011.638372

PUBLISHER

(c) Taylor \& Francis

\section{VERSION}

AM (Accepted Manuscript)

\section{PUBLISHER STATEMENT}

This work is made available according to the conditions of the Creative Commons Attribution-NonCommercialNoDerivatives 4.0 International (CC BY-NC-ND 4.0) licence. Full details of this licence are available at: https://creativecommons.org/licenses/by-nc-nd/4.0/

\section{LICENCE}

CC BY-NC-ND 4.0

\section{REPOSITORY RECORD}

Parvin, Phil. 2019. "Modernism's Legacy: Dialogue, Objectivity, and Justice in Mark Bevir's Democratic Governance”. figshare. https://hdl.handle.net/2134/18266. 
Modernism's Legacy: Dialogue, Objectivity, and Justice in

Mark Bevir's Democratic Governance

In Democratic Governance, Mark Bevir argues that recent developments in the theory and practice of British politics have their intellectual roots in wider trends in the academic study of society and politics. In particular, he argues, the rise in what he and others have called 'the new governance' - that is, the shift in Britain and elsewhere away from centralised policy making and implementation by state institutions toward policy networks in which the state is merely one actor among many - has emerged as a direct consequence of the rise of ahistorical, universalist social science methodologies (Bevir, 2010; see also e.g. R. Rhodes, 1996, 1997). These methodologies, he suggests, create an intellectual environment in which it is assumed that policy decisions are best made by experts rather than citizens, and that 'good governance' is appropriately measured in terms of the efficiency with which policy decisions are made and implemented, rather than the extent to which they reflect the democratic will of the citizens who are to be subject to them. The rise of modernist social science has therefore stifled democratic decision making, he argues, by suggesting (a) that good decision making requires the possession of certain objective facts about society and the people within it, (b) that not everyone will possess these facts, and that, therefore, (c) political decisions should be made by certain people and not others. The upshot of this, he argues, is that while policy making in Britain would appear to have become increasingly democratic and inclusive in recent years - as a result of the increased involvement of non-state actors, interest groups, and lobby organisations - the power to make policy decisions on a range of issues has in fact been centralised among expert individuals and groups, to the detriment of democracy.

Bevir argues against this trend, suggesting that we should reject both the decline in democratic governance that has characterised British political life in recent years, and the modernist social science methodologies which have fuelled it. Once we acknowledge that modernist social science cannot provide the kind of expertise that its defenders think it can, he argues, then the justification for removing citizens from governance, and from policy making and implementation in particular, 
is undermined. Bevir thus concludes that social and political scientists should adopt methodologies which can better cope with the contingencies of lived social experience than those modernist approaches which seek to suppress or elide them. He also argues that, in doing so, social scientists might help to democratise governance by establishing a social, political, and intellectual environment in which the views, aspirations, and insights of citizens themselves might shape the formation and delivery of those policies that effect them.

Bevir's argument is compeling, complex and wide-ranging, and explicitly weaves together two of his enduring preoccupations, namely, the changes in the processes of decision making and policy formation in Britain over the past three decades, and the appropriate methods by which knowledge of social and political life might be gained. (see Bevir, 1999, 2005, 2006a, 2006b, 2006c; Bevir \& Rhodes, 2003; Bevir, Rhodes, \& Weller, 2003). His argument is also far-reaching, drawing upon and contributing to debates in political and social science, political theory, history, and philosophy. His vision of politics, society, and their study is controversial. It is therefore not possible to comment on Bevir's argument in its entirety. Instead, I discuss two central claims in the context of recent developments in the academic literature on democracy and liberalism, and in British politics, in the hope that in doing so it might be possible to evaluate Bevir's claims more widely. The claims I wish to discuss in some detail are (a) that modernist social and political theory presupposes objective standards of reasoning which are incoherent and mistaken, and (b) that policy decisions should be taken by citizens rather than experts.

1. Modernism and the ends of social science

Bevir's argument for the democratisation of governance rests upon his wider rejection of epistemological universalism in social science, and of the assumption of expertise which he sees flowing from it. Modernist social science, he argues, strives to reveal objective laws about society and politics through the observation of social institutions and processes. These laws are grounded in assumptions about rationality most commonly associated either with neo-classical economics or with modern sociology. Those who posit the centrality of economic rationality to the 
study of social behaviour tend to understand social relationships on instrumentalist grounds, as things which either facilitate or impede the satisfaction of individual preferences. Furthermore, they assume people to be 'autonomous individuals whose preferences are formed and whose reasoning is secured outside of all particular cultures' (Bevir, 2010; 261). Those who posit the centrality of sociological rationality, on the other hand, tend to 'replace instrumentality with appropriateness', arguing that acting rationally is not so much about maximising one's individual utility as it is about performing one's social role appropriately, by obeying the various norms attendant to that role (Bevir, 2010; 22). For all their differences, both approaches share an important claim: that it is an important task of the social scientist, if not their most important task, to reveal objective laws of social life grounded in rationality which can explain current and existing behaviour, and predict future behaviour too.

This central assumption unites defenders of economic and sociological rationality in ways that are not often pointed out in the literature. Modernist social science, for Bevir, is premised upon the idea that human behaviour can be explained, and predicted, by an appeal to standards of rationality which are determined independently of any particular social, cultural, or historical context. Modernist social science is both acultural and ahistorical in the sense that sociological rationality and economic rationality are held by their defenders to be capable of stipulating with reasonable certainty what any rational individual will do at any particular time in any particular context: they will either do those things which they think will maximise their individual utility or, if one takes a more sociological view, they will decide whether or not to act in accordance with prevailing social norms. Human behaviour is thus explainable according to standards of rationality which hold true for all people across all cultures and in all times, and hence, it is not necessary for social scientists to engage with the historical or cultural contexts in which individuals exist in order to know how they will act in any given circumstance. Rather, they need only gather enough information about the current ordering of social relations to work out what it would be rational for people to do in the circumstances in which they find themselves. 
The picture that Bevir offers is therefore different to the one we are used to. On the traditional picture, social science is described as being split between those who emphasise economic rationality (and, therefore, the pursuit of objective social facts), and those who emphasise sociological rationality (and, therefore, the importance of social norms and social meanings). The former approach is typically associated with the positivism of thinkers like Auguste Comte, is typically described as arising out of a respect for the advances made in the natural sciences, and is generally held to be most recently exemplified in rational choice theory, behaviouralism, and the economic theories of thinkers like Smith and Hayek. In the field of public policy analysis they are most closely associated with the rise of New Public Management, and specific public sector reforms (such as privatisation and the outsourcing of the delivery of public services to non-state actors) initiated by Neo-Liberals like Margaret Thatcher and Ronald Reagan who were concerned about the power of centralised bureaucracies to dominate the policy making process, undermine efficiency, and stifle radicalism (e.g. Hood, 1991; Barzelay, 2001). The latter approach, on the other hand, tends to be associated with the work of sociologists like Weber and, more recently, Bourdieu, who have in their own ways rejected the straightforward application of natural science methodologies in social science, in favour of an approach which takes into account subjective aspects of social life which they believe are rendered invisible by positivism (Weber, 1922; Bourdieu, 1991).

Bevir controversially argues that both approaches should be rejected, and that both, in their own ways, are associated not just with the kind of reforms initiated by the Neo-Liberals, but also with New Labour's commitment to joined-up government, big tent politics, evidence-based policy, and the desire to tackle social problems via their prior social causes. The reason for this, he suggests, is that positivists and anti-positivists are in fact united in their claim that social science should be concerned with the establishment of universal laws which govern social life, which can be used to explain and predict human behaviour across a range of social contexts, and which, therefore, form the basis of a particular expertise. 'Both modernist economists and modernist sociologists compartmentalize aspects of society so as to manage and explain facts,' he argues. 'They seek to make sense of the particular . . . by reducing it to formal midlevel or universal generalizations 
that hold across time and space' (Bevir, 2010; 23). Consequently, for modernist social scientists of either stripe, the purpose of social science is to establish universal laws that describe demonstrable relations of cause and effect which can be used to inform public policy responses to particular social problems. The resulting policy solutions can then be implemented across society, and across societies. Modernist social science thus equips academics (and, consequently, policy makers) with an expertise in analysing and resolving complex social problems by laying bare the ways in which individuals (understood as rational actors) will act in response to specific social stimuli.

Modernism thus embodies an incoherent epistemological position with regard to social knowledge, he argues. In aiming at the establishment of objective, ahistorical, universal laws of cause and effect, modernist social science ignores the inherently contingent and unpredictable nature of social life, and of our own individual ideas about the world and our place within it. It assumes that social scientists and agents can examine society and politics from the outside, from a plateau of pure reason which exists separately from, or above, society, and that they are therefore able to reason about society and politics in a way that is untainted by their own particular ideas, values, and experiences. Bevir asks that we reject this approach, in particular the idea that the content of rationality can be stipulated independently of the context in which social actors find themselves. Reasoning, he suggests, 'always takes place against a background of a particular subjective or intersubjective web of beliefs. While the content of the relevant web of beliefs varies from case to case, there is no possibility of reasoning outside of any such background.' (Bevir, 261, emphasis added).

In this respect, Bevir's rejection of modernist social science, the expertise arising from it, and the appeal to objective reason that it embodies, can be seen to share the same root as claims made by other thinkers from across the political spectrum who have, for one reason or another, rejected the appeal to universal reason as an appropriate source of knowledge about society, politics or anything else. For all their many differences, communitarian critics of liberalism (e.g. Sandel 1982,1986; Maclntyre, 1988; Taylor, 1992, 1995), poststructuralist critics of rationalism (e.g. 
Foucault, 1989), and critical theorists of positivism (e.g. Adorno, 1973; Habermas, 1989) are nevertheless united with other philosophers like Hillary Putnam, W.V.O. Quine, Richard Rorty, and Bernard Williams in questioning the idea that knowledge can be, and should aspire to be, objective and universal rather than subjective and particular (Putnam, 1990; Quine, 1951, 1960, 1970; Rorty, 1989; Williams, 1972). Thomas Nagel has identified the work of these philosophers as exemplifying a rise in philosophical subjectivism (Nagel, 1997). Bevir has associated them with the emergence of what he calls 'post analytic' philosophy (Bevir, 1999). Whatever we choose to call it, however, the conclusion for Bevir is clear: once we take seriously the embeddedness of individual agents in particular cultural, social, and political frameworks we are forced to relinquish the modernist presumption that it is possible (or appropriate) to adopt a 'view from nowhere' and to reason about the world from a plateau of unfettered reason which exists independently of our various attachments and memberships, and which determines what is 'rational' for us to do in any given context. Social and cultural particularity undermines the universality sought by modernist social science, he argues, and hence, the point of social science is not to come up with timeless laws rooted in universal norms of rationality, but to describe and explain social behaviour in terms of the overlapping and often conflicting ideals, understandings, and aspirations of those actors involved. It is, in fact, to come up with a conception of rationality the content of which arises out of the social, political, and cultural context in which agents are embedded. Social particularity, or contingency upsets the notion of expertise based on universal insights about human behaviour, and points to the changeable, contextual nature of our behaviour, as well as the importance of our own subjective ideas about the world in our decisions about how to act in response to the particular circumstances in which we find ourselves. Social science, far from being the pursuit of ahistorical, universal laws of cause and effect, he argues, should be interpretive: the social and political scientist should not stand aloof from her subject matter, but should study it from the inside, through an engagement with the subjective, ambiguous, and complex ideas and perceptions held by situated agents.

2. Democracy, objectivity, and dialogue 
Bevir's argument is radical, both for epistemology and for politics. It strikes against positivists, rational choice theorists, behaviouralists, and others who have assumed the importance of economic rationality in explaining and predicting social behaviour, and who believe that it is possible and appropriate to characterise all human action as the result of a calculation about what best maximises one's own individual utility. It also strikes against defenders of sociological rationality who assert that rationality is simply, and in all cases, defined as submission to the norms and obligations arising out of one's social roles. It has radical epistemological implications as it suggests that because our knowledge of the world is inevitably shaped by the background context of subjective values and meanings against which we reason, objective, universal knowledge is neither desirable nor possible. Politically, it is radical because in rejecting the concept of objective reason, Bevir not only rejects rational choice theory, behaviouralism and all those other academic approaches mentioned thus far. He also necessarily and explicitly rejects the liberal tradition, which has come to dominate Anglo-American political theory and practice, and which is the political expression of the modernist ideals that Bevir is against.

Bevir has long been a critic of liberalism, and in Democratic Governance rejects it in favour of what he calls the radical democratic tradition (Bevir, 2001, 2005, 2010). The reason for this, straightforwardly, is that liberal politics is itself part of the problem: it cannot offer an alternative to modernist notions of universalism, ahistoricism, and individualism, because it is itself premised upon these very notions. Just as modernist social scientists have sought to establish social laws which are defined independently of the particular lived experiences of the individuals they describe, so liberal theorists have sought to establish rules of social and political life which draw their authority not from of the ideals or lived experiences of the people governed by them, but from wider, deeper truths about humanity and morality which are revealed by objective reason (e.g. Rawls, 1971, 1991 \& 2002; Dworkin, 2002). That is, while modernist social scientists have provided the intellectual argument for the centralisation of political power among experts of one kind or another, liberal political theorists have shown how this might be done. Liberals have, in general, carried forward modernist aims by defending the establishment of representative institutions and constitutional arrangements aimed at keeping power out of the hands of citizens 
in general, and in the hands of those experts (judges, politicians, etc.) who have shown themselves to be capable of ruling in accordance with those wider, deeper moral rules revealed by objective reason. For Bevir, then, the democratisation of governance thus requires a rejection of the epistemological assumptions of modernism, its founding principles, and the liberal constitutionalism justified by it. It requires not just an interpretivist social science, but a more radical, democratic conception of society and politics premised upon substantive dialogue among historically and culturally embedded interlocuters, and a policy making process grounded in agreement and dialogue among situated agents as opposed to objective rules or principles revealed by experts.

Herein lies a problem, however. Bevir's claim that modernist social and political theory requires agents to adopt a 'view from nowhere' in order to derive universal, ahistorical grounds for the resolution of political questions is common among critics of liberalism, especially those who seek to replace what they see as the dull, elite-driven managerialism of liberal politics with a richer, more radically democratic model (Bevir, 2010). Radical democratic thinkers like Ernesto Laclau, Chantal Mouffe, Nancy Fraser, and Iris Marion Young have chastised liberals for their metaphysical and epistemological incoherences. For example, Young sought to debunk the empty notion of objectivity at the heart of liberalism in much the same ways as does Bevir, suggesting that it rests on the mistaken notion that parties to political dialogue should, in the interests of resolving political questions, 'adopt a point of view outside concrete situations of action, a transcendental "view from nowhere" that carries the perspective, attributes, character and interests of no particular subject or subjects.' (Young, 1990; 100). Bevir's claim that it is 'impossible' for people to reason outside of the framework of values and beliefs provided for them by the social context in which they are embedded, Young's claim that 'participants in political discussion cannot transcend their particularity', and so on, are thus examples of a widespread and popular critique of not just of liberalism, but, more importantly, of the 'modernist' ideals upon which it is founded. (Young, 2000; 113). Young, like Mouffe, Laclau, and others like Fraser have generally invoked this argument against liberals in order to advance an alternative model of 
politics grounded in dialogue among situated agents, which, they think, avoids the need to invoke an unrealistic conception of reason or the individual (Laclau \& Mouffe, 1985; Fraser, 1997).

But the argument that people are embedded in webs of belief which they find 'impossible' to reason outside of does not represent an argument for a more democratic model of politics. This is because in order for democratic politics to yield the kind of agreements on matters of policy and institutional design that Bevir and others envisage, participants in political dialogue must be capable of doing precisely that which Bevir, Young, and others claim is impossible: they must be capable of establishing the requisite cognitive distance between 'themselves' and those 'webs of belief' which define and shape them to discuss them meaningfully with others who do not share them.

Bevir is right that modernist social and political thought - and liberalism in particular - does indeed require individuals to abstract themselves from their particular ideals and lived experiences. But it does so in a particular way for particular reasons. Liberalism represents a pragmatic response to the specific problem of political disagreement and the possible conflicts which can arise out of it. That is, it represents a response to the fact that differently situated groups and individuals will often disagree profoundly about the right policy or course of action and that these disagreements will often not be resolvable without recourse to violence without an appeal to principles or rules which are not located in any particular tradition or set of experiences, but in more general claims which all parties to the dialogue can agree with irrespective of their more particular disagreements about more substantive matters. Locke's defence of the principle of toleration was, after all, rooted in the observation that if state institutions were to be considered legitimate by a population divided on questions of religious truth, then these institutions must necessarily draw their legitimacy independently of any particular account of religious truth (Locke, 1689 \& 1690). This theme remains dominant in more recent incarnations of liberalism too, particularly those 'political' forms of liberalism advanced by thinkers like John Rawls, Martha Nussbaum, and Charles Larmore, who seek to legitimate a liberal democratic order via agreements arising out of the exchange of public reasons which are themselves not grounded in particular ideals or 'webs 
of belief' (Rawls, 1991; Nussbaum, 1999; Larmore, 1987 \& 1995). Contrary to the claims made by communitarian and other critics of liberalism, therefore, liberalism - and the modernist ideas upon which it is founded - does not presuppose the existence of individuals who are somehow understood in abstraction from the contexts which give their lives meaning, or that they must adopt a 'view from nowhere'. Rather, it begins precisely in the assumption that people are deeply embedded in particular webs of belief, and that they will have particular ideals and values which they cherish and which they could not relinquish, which is precisely why controversial political questions cannot be legitimately resolved by an appeal to any one particular web of belief or set of values. Rather, they argue, the legitimate resolution to political questions such as the appropriate design of institutions and policies, come from a process of reflective deliberation among agents who are understood to have been shaped by the contexts in which they find themselves. The objectivity sought by liberalism is political not ontological. Individuals who are understood to be situated in particular contexts but who are also genuinely motivated to find agreement on constitutional and policy matters will, when faced with profound disagreement, voluntarily modify their language in ways which move the argument onto more common ground. They will, that is, seek grounds for agreement which are more 'objective' in the sense that they are not rooted in any particular account of the good life, or set of lived experiences, in order that they can gain the assent of radically different people, from different traditions, who are embedded in different webs of belief.

It is this voluntary move on the part of the parties to political dialogue from the particular to the general - the subjective to the objective - which Bevir, Young, and others would appear to believe is impossible. But this is a very strong claim indeed, and one which appears to undermine both the possibility of a liberal form of politics and a more radically democratic one. For if people are just unable to establish sufficient distance from any of their particular values, beliefs, ideals, or experiences to discuss them in ways which others can find intelligible, then it is difficult to envisage the prospect of any kind of agreement on political questions at all. Political dialogue between such radically situated agents will end in stalemate. 
Liberals suggest that such a conclusion can be avoided because it is possible and appropriate for parties to political dialogue, if they are genuinely motivated to reach agreement with others, to offer reasons for and against particular proposals and arguments which are 'objective' in the sense that they are not rooted entirely in controversial or partial accounts of truth, or beliefs or ideals which are not stipulated by particular webs of belief. Bevir, Young, and other critics of liberalism (or the modernist principles upon which it is founded) reject this approach as embodying a 'view from nowhere'. They are therefore required to come up with an alternative explanation of how diverse individuals, all of whom are so firmly embedded in their webs of belief that to think beyond them for the purposes of reaching political agreements is impossible, can nevertheless converge on agreements which are substantive enough to legitimate specific policy outcomes, institutional arrangements, and constitutional provisions which are considered appropriate and supportable by all. Bevir has touched on this elsewhere, arguing that such agreement is possible as long as the deliberative process is conceived as a discourse between situated individuals who view one another as equals with whom they feel empathy (Bevir, 2001). But this does not deal with the liberal concern that radically different people may be so divided over matters of substance that they may find empathy difficult or even impossible. Bevir says little more on the matter in Democratic Governance and instead speaks in vague terms about the need for a 'pluralist and participatory democracy built around diverse openings and support for citizens to develop voice, enter dialogues, and rule themselves.' (Bevir, 2010; 273) But while participation and dialogue are all very well, it is difficult to see what these dialogues might yield in terms of policy outcomes if the parties to them are, as he suggests, unable to look beyond their own subjective location in the world and the values which arise out of it.

\section{Democracy, expertise, and social justice}

In spite of all this, Bevir is nevertheless correct that modernist social and political theory, as exemplified in liberalism, tends to favour a constitutional regime in which the agreements struck between parties to political debate are used to justify the centralisation of decision-making power in representative institutions and non-majoritarian institutions, while the radical democratic 
tradition rejects such a move in favour of the retention of power among individuals themselves. Bevir is also right that talk of representative democracy has dominated political discourse in developed liberal democratic states and in Britain in particular.

Recently, however, this has begun to change. Within the academy there has been a widespread and explicit move among many democrats to redefine democracy as a deliberative rather than representative system (e.g. Cohen, 1989; Fung \& Wright, 2001; Gutmann \& Thompson, 1998, 2004). And outside the academy, a similar shift seems to be taking place. One of the most striking things about British politics in the past three or four years, for example, is the extent to which the dominant discourse of evidence-based policy, benchmarking, and joined-up government has been replaced by a wider cross-party unity on the need for stronger local democracy, civic renewal, and the devolution of power away from governmental or quasigovernmental organisations toward citizens. The run-up to the 2010 general election saw all the main parties, and the vast majority of the more marginal ones, abandon traditional appeals to representative democracy and unite instead on the need for some form of localism. New Labour 'progressives' argued for the devolution of power away from central institutions toward citizens in the interests of extending the 'choice agenda' (e.g. Milburn et al, 2008). The Liberal democrats and the Conservatives argued for richer local democracy, partly as a reaction to recent concerns among the electorate about MPs' expenses and other scandals, but also in order to free citizens and local communities from the tyranny of non-elected experts residing in quangoes, or in the institutions of Europe, or elsewhere (e.g. Cameron et al, 2009). Furthermore, UKIP, the Green Party, the English Democrats, and the British National Party joined with more mainstream parties in stating in their manifestoes that the future for democratic reform in Britain lay in bringing power closer to the people. Think tanks from the left, right and centre of British politics have also embraced the general call for local democracy, with organisations as politically diverse as Policy Exchange, IPPR, the New Economics Foundation, and Civitas all arguing in favour of the idea that in the interests of strengthening democracy, power should move from central institutions (and, hence, from elected and non-elected experts) to local people who are better placed to 
identify local priorities and provide targeted policy solutions to local problems (e.g. Jenkins, 2004; McCarvill, 2010; Boyle, 2009; Beedham, 2006).

Since its election in May 2010, the coalition government has proposed a raft of initiatives aimed at making good on this commitment to local democracy and, in particular, to the power of ordinary citizens to influence the funding and delivery of public services. Furthermore, it is clear that these reforms are driven by an explicit rejection of the idea of expertise, and of the elitest methods which Bevir identifies as driving policy formation and implementation under New Labour. One of the arguments made by ministers in favour of Free Schools, for example, is that they will wrest education from the grasp of experts and allow parents to set up and run schools as they see fit. Similarly, the idea that local policing priorities should be set by local people via elected police chiefs rests on the assumption that decisions about policing priorities, crime prevention, and police budgets should not be made by experts but by citizens. And the idea that decisions about such complex issues as planning, transport, and the provision of health and care services should be made by local people rather than MPs, Regional Development Agencies, Quangoes, or European Institutions suggests that it is one's status as a citizen (or, more specifically in the case of localism, a resident of a particular geographical area) which renders one qualified to decide public policy as opposed to any particular expertise, specialised training, or experience. What we see in the localist agenda, therefore, is a break from centralised policy making but also, more fundamentally, a break from the need for 'evidence-based' policy, benchmarking, and the like. Policy decisions in this new climate are deemed legitimate or illegitimate depending upon the extent to which they are in accord with the expressed democratic will of the people who are to be subject to them, rather than the extent to which they are rooted in evidence gathered and analysed by social scientists.

The widespread shift away from the traditional discourse of representative democracy toward a more localist, deliberative form of politics raises important questions about Bevir's depiction of British politics. In one sense, it vindicates it. Bevir's rejection of expertise and evidence-based policy, characteristic of New Labour and the Neo-Liberalism of the 1980s, appears to resonate 
with what has become a popular scepticism among politicians and the public about the ability of experts to provide the kind of certainty necessary to justify centralised, elitist decision making. Even the wisdom of legal experts and judges have come under scrutiny, with increasing numbers of politicians and campaigners arguing that decisions about the sentencing of criminals should be devolved down to citizens (see e.g. Carswell \& Hannan, 2005, 2008). Bevir's analysis of the situation in Britain goes a long way in explaining the deep-seated cynicism among the public about British democracy, and about the motives of politicians: it provides an analytical and historical explanation for the common (and, it seems, growing) feeling among the public that elections are becoming less and less meaningful, as policy decisions are becoming increasingly the province not of elected representatives, but an unelected coterie of advisors, activists, groups, and organisations who are assumed to have the knowledge and expertise necessary to govern on behalf of the ignorant masses.

On the other hand, however, the increased willingness among politicians, political practitioners, activists, and the media to embrace a more deliberative form of politics in place of traditional representation makes clearer the potential problems with such an approach. The most obvious of these, and one which Bevir himself identifies, is the tension between the desire to establish more democratic forms of politics with the concurrent desire to ensure greater social justice among the population as a whole. One of the most powerful arguments in favour of representative democracy is that powerful, reflective institutions which are grounded in the popular assent of the people are more able to make difficult (and often unpopular) decisions in the name of social justice than more radically democratic ones. Society is characterised by diversity on a huge scale, the argument goes; different citizens have different ideals and values, different experiences, have access to different resources, and require different things from democratic institutions. Not everyone can get what they want all the time: citizens will have competing desires, and will make competing claims for scarce resources. In such circumstances it is important that our political representatives are able to make reflective and responsible choices even though, in doing so, they will inevitably cause some to be disappointed or resentful at the outcome. Representative institutions arguably ensure a degree of fairness in the resolution of political conflicts which is 
absent in more deliberative systems in which decisions are taken by the people at large, and they defend minority interests against the overbearing majority, and hence, help to provide a normative justification for policies such as the alleviation of poverty, progressive taxation, and the protection of minority cultural and religious practices.

The call to reduce the role of central representative institutions in the decision making process and increase the decision making of citizens as a whole raises the question of how the democratic safeguards traditionally provided by liberal constitutionalism and representative democracy might be otherwise maintained (or, more fundamentally, what their justification might be in a more radically democratic context). One particular issue here is the fact that deliberative decision making procedures run the risk of entrenching precisely the kind of pre-existing inequalities that representative democracy is (when working properly) designed to remedy, and social democrats in particular are most concerned about. For example, Bevir notes that many liberal democratic states are experiencing declining levels of political engagement among their citizens. But arguably, the problem is not so much the widespread disengagement of citizens with formal and informal political activities, but rather the disproportionately high levels of political engagement among citizens of a high socio-economic status, and the disproportionately low levels of engagement among those of a low socio-economic status. As countless studies have shown, propensity to engage in a range of civic and political activities, from voting, lobbying MPs, and attending local political meetings, to signing petitions and taking part in demonstrations is closely associated with the level of education and economic resources citizens have at their disposal, with wealthier, more educated citizens engaging at significantly higher rates across the board than poorer, less educated ones (e.g. Lijphart, 1997; Macedo et al, 2005; Hansard Society \& Electoral Commission, 2008; Parvin, 2005, 2009, 2010; Verba, Schlozman, and Brady, 1995; Chong \& Olivera, 2008; Keany \& Rogers, 2006; Muller, 1988). This fact brings the tension between democracy and social justice into sharp relief. For if we are at all concerned about social justice, then the answer to our concerns about democracy cannot simply be to hand power down to citizens. Straightforwardly devolving power down to local people, or to citizens in general, merely places power in the hands of those citizens who are already politically active, and who 
have the inclination and resources necessary to make use of the power that they are given, and excludes those who are not, and do not have these resources. There is a danger, therefore, that Bevir's vision of a more deliberative, dialogic model of decision making and policy formation would make it easier for the middle classes to dominate policy making, and to drive through decisions which address their concerns at the expense of the concerns of others.

We see concerns of precisely this kind in Britain aired by those who remain sceptical of the desire among politicians and others to devolve decision making power down to local communities and citizens. Their concern is, broadly speaking, that under such a system the tyranny of experts is merely replaced by the tyranny of the wealthy (e.g. Walker, 2002a, 2002b; Parvin, 2009). Hence, they say, the British government's plan to wrest power from experts in the areas of education, policing, planning, and so on will inevitably disproportionately benefit the most advantaged members of society at the expense of the least advantaged as it will be they who run the Free Schools, decide what the police should spend their time doing, decide what kind of health care should be provided in their area, and what buildings get planning permission in their neighbourhoods. Advocates of deliberative or dialogic policy making therefore need to explain how they will safeguard against this. Bevir does not do so, although he at least acknowledges that it is a problem. Elsewhere, for example, he has suggested that his 'postfoundationalist' conception of democratic dialogue would produce socially just outcomes by encouraging all participants to 'treat each other as they do themselves' by ensuring that they all have the 'level of mutual comfort, education, and the like' to pursue their own good in their own way (Bevir, 2001; 60-61). In Democratic Governance, Bevir offers a similar vision of democratic deliberation in which diverse people get together to share their stories and, through doing so, come to converge on decisions which are fair and inclusive. This is a noble hope, and one which most democrats and liberals would support. But Bevir does not provide much guidance as to what should be done if participants in political dialogue do not, or are not able to, treat one another as Bevir hopes they will. Parties to dialogue may well understand, through the mutual 'telling of stories' within a democratic forum, that people need an appropriate bundle of social, economic, and other resources in order to pursue their particular ends, but they might (collectively or individually) 
reject the ends that some people want to pursue as unworthwhile or mistaken. Such disagreements about what makes life worthwhile, and how people should live their lives, is the very stuff of politics. The collective telling of stories via democratic discourse may well make the aims and interests of interlocutors more transparent to all involved, but it does not follow that these same interlocutors will look kindly or humanely on these interests. They may learn that they dislike or even hate them. What then? Again, without a more detailed explanation of how the ideals of democracy and social justice might be reconciled in the absence of representative institutions and liberal constitutional checks against the whims of majorities and fellow deliberators, Bevir's positive argument for democratic governance can only be a partial one.

\section{Bibliography}

Adorno, T.W., (1973) Negative Dialectics (London: Routledge).

Barzelay, M., 2001, The New Public Management: Improving Research and Policy Dialogue (Berkeley, CA: University of California Press).

Beedham, B., 2006, The Case for Direct Democracy (London: Civitas).

Bevir, M., 2010, Democratic Governance (Princeton, NJ: Princeton University Press).

Bevir, M., 2006a, Governance Stories (London: Routledge).

Bevir, M., 2006b, 'A Decentered Theory of Governance', H. Bang (ed) Governance as Social and Political Communication, pp. 200-221. (Manchester: Manchester University Press).

Bevir, M., 2006c, 'Political Studies as Narrative and Science, 1880-2000'. Political Studies 54, pp. 583-606.

Bevir, M., 2005, New Labour: A Critique (London: Routledge).

Bevir, M. \& R. Rhodes, 2003, Interpreting British Governance (London: Routledge).

Bevir, M., R. Rhodes \& P. Weller (eds), 2003, 'Traditions of Governance: History and Diversity' Special Issue Public Administration 87/1.

Bevir, M., 2001, 'Postfoundationalism and Social Democracy', Teorema, pp. 55-71.

Bevir, M., 1999, The Logic of the History of Ideas (Cambridge: Cambridge University Press).

Bourdieu, P., 1991, In Other Words: Essays Toward a Reflexive Sociology (Cambridge: Polity 
Press).

Boyle, D., 2009, Localism: Unravelling the Supplicant State (London: New Economics Foundation).

Cameron, D. et al, 2009, Control Shift: Returning Power to Local Communities (London: Conservative Party).

Carswell, D. \& D. Hannan, 2005, Direct Democracy: An Agenda for a New Model Party (London: Carswell).

Carswell, D. \& D. Hannan, 2008, The Plan: Twelve Months to Renew Britain (London: Carswell).

Chong, A. \& M. Olivera, 2008, 'Does compulsory voting help equalize incomes?' Economics \& Politics 20/3, pp. $391-415$.

Cohen, J., 1989, 'Deliberation and Democratic Legitimacy', The Good Polity (London: Blackwell).

Dworkin, R., 2002, Sovereign Virtue: The Theory and Practice of Equality (Cambridge, MA: Harvard University Press).

Foucault, M., 1989, The Order of Things (London: Routledge).

Fraser, N., 1997, Justice Interruptus:Critical Reflections on the 'Post-Socialist' Condition (London: Routledge).

Fung, A. \& E.O. Wright, 2001, 'Deepening Democracy: Innovations in Empowered Participatory Governance', Politics and Society 29, pp. 5-41.

Gutmann, A. \& D. Thompson, 1998, Democracy \& Disagreement (Cambridge, MA: Harvard University Press).

Gutmann, A. \& D. Thompson, 2004, Why Deliberative Democracy? (Princeton: Princeton University Press).

Habermas, J., 1989, The Structural Transformation of the Public Sphere: An Inquiry into a Category of Bourgeois Society (Cambridge: Polity Press).

Hansard Society \& Electoral Commission, 2009, An Audit of Political Engagement 6 (London, Hansard Society).

Hood, C., 1991, 'A Public Management for all Seasons?' Public Administration 69, pp. 3-19.

Jenkins, S., 2004, Big Bang Localism: A Rescue Plan for British Democracy (London: Policy Exchange and Localis). 
Keany, E. \& B. Rogers, 2006, A Citizen's Duty: Voter Inequality and the Case for Compulsory Turnout (London: Institute of Public Policy Research).

Laclau, E. \& C. Mouffe, 1985, Hegemony and Socialist Strategy (London: Verso).

Larmore, C. (1995) The Morals of Modernity (Cambridge: Cambridge University Press).

Larmore, C. (1987) Patterns of Moral Complexity (Cambridge: Cambridge University Press).

Lijphart, A., 1997, 'Unequal Participation; Democracy’s Unresolved Dilemma,' American Political Science Review 91/1, pp. 1-14.

Locke, J., 1690., Two Treatises of Government, P. Laslett (ed.), 1998 The Two Treatises of Government (Cambridge: Cambridge University Press).

Locke, J., 1689, 'A Letter Concerning Toleration', in S. Mendus \& J. Horton (eds.), 1991, A Letter Concerning Toleration in Focus (London: Routledge).

Macedo, S. et al, 2005, Democracy at Risk: How Political Choices Undermine Political Choices Undermine Citizen Participation, and What We Can Do About It (Washington DC: Brookings Institution).

Maclntyre, A., 1988, Whose Justice? Which Rationality? (Notre-Dame: University of Notre-Dame Press).

McCarvill, P., 2010, Equality, Entitlements, and Localism (London: Institute for Public Policy Research).

Muller, E., 1988, 'Democracy, Economic Development, and Income Inequality,' American Sociological Review 53, pp. $50-68$.

Nagel, T., 1997, The Last Word (Oxford: Oxford University Press).

Nussbaum, M., 1999, 'A Plea for Complexity' in J. Cohen, M. Howard, \& M. Nussbaum (eds.) Is Multiculturalism Bad for Women? (Princeton, NJ: Princeton University Press).

Parvin, P., 2009, 'Against Localism: Does Devolving Power to Communities Fail Minorities?', The Political Quarterly 80/3, pp. 351-360.

Parvin, P., 2010, 'Power to the people or Entrenching Inequality?', Public Servant, November, p. 13.

Parvin, P. \& D.McHugh, 2005, 'Defending Representative Democracy: Political Parties and the Future of Political Engagement in the UK', Parliamentary Affairs 58/3, pp. 632-655. 
Putnam, H., 1990, 'After Empiricism', Realism with a Human Face (Cambridge, MA: Harvard University Press), pp. 43-53.

Quine, W.V.O., 1951, 'Two Dogmas of Empiricism', The Philosophical Review 60, pp. 20-43.

Quine, W.V.O., 1960, Word and Object (Cambridge, MA: Harvard University Press).

Quine, W.V.O., 1970, The Web of Belief (New York: Random House).

Rawls, J., 1971, A Theory of Justice (Oxford: Oxford University Press).

Rawls, J., 1991, Political Liberalism (New York: Columbia University Press).

Rawls, J., 2001, Justice as Fairness: A Re-Statement (Cambridge, MA: Harvard University Press).

Rhodes, R., 1996, 'The New Governance: Governing without Government', Political Studies 44/4, pp. 652-667

Rhodes, R., 1997, Understanding Governance: Policy Networks, Governance, Reflexivity, and Institutions (Buckingham: Open University Press).

Rorty, R., 1989, Contingency, Irony, and Solidarity (Cambridge: Cambridge University Press).

Sandel, M. J., 1982, Liberalism and the Limits of Justice (Cambridge: Cambridge University Press).

Sandel, M. J., 1996, Democracy's Discontent: America in Search of a Public Philosophy (Cambridge, MA: Harvard University Press).

Taylor, C., 1992, The Ethics of Authenticity (Cambridge, MA: Harvard University Press).

Taylor, C., 1995, 'Cross-Purposes: The Liberal-Communitarian Debate', Philosophical Arguments (Cambridge, MA: Harvard University Press).

Verba, S., K. Schlozman, \& H. Brady, 1995, Voice and Equality: Civic Volunteerism in American Politics (Cambridge, MA: Harvard University Press).

Walker, D., 2002a, 'Hold the Centre', The Guardian, November $21^{\text {st }}$.

Walker, D., 2002b, In Praise of Centralism: A Critique of the New Localism (London: Catalyst Forum).

Weber, M., 1922, 'The Nature of Social Action' in W.G. Runciman (ed.), 1991, Weber: Selections in Translation (Cambridge: Cambridge University Press).

Williams, B., 1972, Morality: An Introduction to Ethics (New York: Harper and Row). 
Young, I. M., 1990, Justice and the Politics of Difference (Princeton, NJ: Princeton University Press).

Young, I. M., 2000, Inclusion and Democracy (New York: Oxford University Press). 